\title{
User Experience and User Satisfaction Analysis of Learning Assistance Services (Tuweb, Tuton, TMK) at UPBJJ-UT Bengkulu
}

\author{
Pamela Mikaresti $^{1 *}$, Yusrizal $^{2}$, Ana Nurmalia ${ }^{3}$ \\ ${ }^{1 *, 2}$ Faculty of Education and Teacher Training, Open University \\ ${ }^{3}$ Faculty of Agriculture, Dehasen University \\ *Corresponding Author. Email: pamela@ecampus.ut.ac.id
}

\begin{abstract}
The purpose of this study was to analyze user experience and user satisfaction for learning assistance services, namely web-based tutorials, online tutorials and course assignments. The research method used is descriptive quantitative. The number of samples is 540 respondents, namely students. The instrument used is a questionnaire which is shared with google form. The data analysis technique of this research uses the Likert scale method and multiple linear regression. The results showed that the three learning aid services had positive user experience and user satisfaction. More than $75 \%$ of respondents rated the user experience and user satisfaction of TUWEB, TUTON and TMK as being in the good and high categories. TUWEB, TUTON and TMK study assistance services are available to meet the needs of various students. Students who like to study more intensely, can interact virtually in two directions via video conferencing will choose TUWEB. Students who find it difficult to find a scheduled time and prefer to study with a more flexible but still focused time will choose TUTON. As for students who do not want to take part in TUWEB or TUTON, there is a more practical TMK. Variables that have a significant effect on user satisfaction of TUWEB learning aid services are dependability and stimulation. Variables that have a significant effect on user satisfaction of TUTON learning aid services are attractiveness, perspicuity and stimulation. Variables that have a significant effect on user satisfaction of TMK learning aid services are efficiency and novelty.
\end{abstract}

Article History

Received: 14-09-2021

Revised: 26-10-2021

Accepted: 16-11-2021

Published: 11-12-2021

Key Words:

User Experience,

User Satisfaction,

Study Assistance

Services, TUWEB,

TUTON and TMK.

How to Cite: Mikaresti, P., Yusrizal, Y., \& Nurmalia, A. (2021). User Experience and User Satisfication Analysis of Learning Assistance Services (Tuweb, Tuton, TMK) at UPBJJ-UT Bengkulu. Jurnal Kependidikan: Jurnal Hasil Penelitian dan Kajian Kepustakaan di Bidang Pendidikan, Pengajaran dan Pembelajaran, 7(4), 981-993. doi:https://doi.org/10.33394/jk.v7i4.4141

https://doi.org/10.33394/jk.v7i4.4141

This is an open-access article under the CC-BY-SA License.

\section{Introduction}

The Open University (UT) is a public university that implements an open and distance learning system (Open University, 2015). UT learning is open, i.e. there is no age limit, study period, year of diploma, etc., while distance means a system in which learning is not conducted face-to-face (Rosali et al., 2020). While distance learning is learning that can be done without face to face or online. Online learning is considered conventional which is able to train user digitization (Harjanto \& Sumunar, 2018). Learning is carried out with various efforts, one of which is by displaying learning videos (Abidin et al., 2020). Learning is carried out with internet-based media/applications, namely; animated videos, youtube, google classroom, whatsapp, google meet, zoom and others (Didik, 2020). The creativity and competence of teachers are needed to create interesting and effective learning (Aji, 2020). Online learning is often constrained by costs and internet networks so efforts are needed to minimize these obstacles (Artayasa, et al., 2021)

The Distance Learning Program Unit (UPBJJ) of UT Bengkulu is one of the best technical implementers. There are 40 UT UPBJJs in Indonesia, in the 2015-2020 UT 
strategic plan which focuses on resource management, academic services and increasing the number of students (Sil, 2018). In order to improve academic services, UT has provided two types of learning assistance in the form of tutorial services, namely face-to-face tutorials and online tutorials. Face-to-face learning assistance services are one of the most popular assistance services for students. However, the spread of Covid-19 in the world including in Indonesia at the end of 2019 had an impact on all sectors including education. The government decided on an online learning policy to minimize the transmission of the virus. The Ministry of Education and Culture (Kemendikbud) issued Circular Letter Number 4 of 2020 concerning Guidelines for Organizing Learning from Home in an Emergency Period for the Spread of Covid-19 (Kemdikbud Education and Training Center, 2020). So that UT provides alternative learning assistance services such as webinars tutorials and course assignments as an option for learning assistance services because face-to-face tutorials are not possible. So that the currently available study assistance services are web-based tutorials (TUWEB), online tutorials (TUTON) and course assignments (TMK).

TUWEB is a web-based study assistance service with an application with the help of a tutor. TUWEB is implemented with a video conference application and with tutor directions and is reported in the LMS application. TUTON is an online learning assistance service using E-Learning. While TMK is a service available in the form of course assignments for students who do not register for TUWEB or TUTON (Open University, 2020).

So far, no research has been conducted on user experience and user satisfaction with the three learning aid services. For this reason, it is necessary to analyze user experience and user satisfaction to determine user experience and user satisfaction with learning assistance services, namely web-based tutorials, online tutorials and course assignments. For user experience analysis, it is intended to find out how users evaluate and feel after using services / software (Cerejo, 2012). In addition, an analysis is carried out that affects the satisfaction of service users. This is done to find out what indicators affect the satisfaction of users of TUWEB, TUTON, TMK learning aid services so that they can be used as a reference for service improvement. Therefore, it is important to conduct this research with the aim of analyzing user experience and user satisfaction for learning assistance services, namely webbased tutorials, online tutorials and course assignments.

\section{Research Method}

The research method used is descriptive quantitative. This research was carried out in all areas of UPBJJ-UT Bengkulu. The population of users of TMK learning assistance services at UPBJJ-UT Bengkulu is 5400, so according to Arikunto (2002) sampling from a population above 1000 can be taken as much as $10 \%$, so a sample of 540 respondents is obtained. To analyze the level of user experience and user satisfaction using descriptive analysis. Descriptive analysis is used to describe the actual situation, it can be with the help of graphs or so on (Nurgiantoro, 2009). The primary data obtained were analyzed for levels using a Likert scale. (Shim and Siegel, 2011).

In analyzing the user experience and user satisfaction data obtained from the questionnaire, a Likert scale was used. According to Nazir (2014) that the Likert Scale is a psychometric method for analyzing a program. For the assessment of each indicator $=$ Total Score per Indicator/Number of Respondents. Questionnaires were obtained from various literature studies which would be sent to each user of the TUWEB, TUTON and TMK learning aid services. 


\section{User Experience}

Table. 1. User Experience Questionnaire Table For Learning Assistance Services in UPBJJ-UT Bengkulu

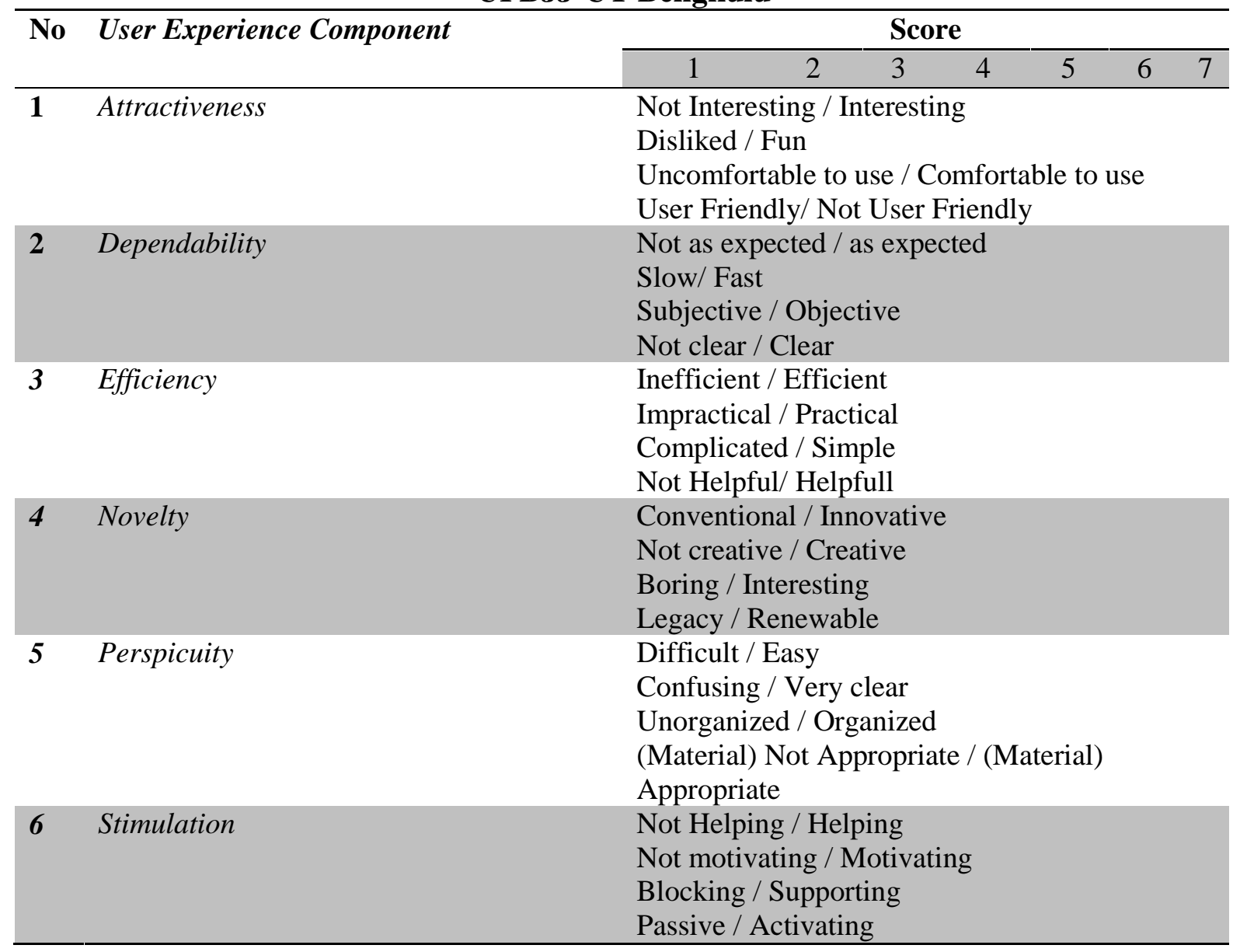

Source: Siregar (2019) and Wijaya (2021)

The assessment criteria are as follows:

$1=$ very No

$2=$ less

$3=$ slightly less

$4=$ enough

$5=$ slightly good

$6=\operatorname{good}$

$7=$ very good

So that the application example in the first question (attraction) is as follows:

Answer :

$1=$ very unattractive

$2=$ less attractive

$3=$ a little less attractive

$4=$ quite interesting

$5=$ slightly interesting

$6=$ interesting 


\section{User Satisfication}

Table. 2. User Satisfication Questionnaire Table For Learning Assistance Services in UPBJJ-UT Bengkulu

No User Satisfication Component

\begin{tabular}{lc}
\hline $\mathbf{1}$ & Content \\
$\mathbf{2}$ & Accuracy \\
$\mathbf{3}$ & Format \\
$\mathbf{4}$ & Ease of Use \\
$\mathbf{5}$ & Timeliness \\
\hline
\end{tabular}

Source: Wisudiawan (2013)

Information:

Strongly Agree : :5

Agree $\quad: 4$

Doubtful :3

Disagree $\quad: 2$

Strongly Disagree : 1

According to Sugiyono (2014) that: "Multiple linear regression analysis aims to determine the effect of the dependent variable with several independent variables. The total number of independent variables is at least 2 variables".

$\mathrm{Y}=\alpha 0+\alpha 1 \mathrm{X} 1+\alpha 2 \mathrm{X} 2+\alpha 3 \mathrm{X} 3+\alpha 4 \mathrm{X} 4+\alpha 5 \mathrm{X} 5+\alpha 6 \mathrm{X} 6+\mathrm{u} . \ldots$

Information:

$\mathrm{Y}$

$\mathrm{X} 1$

$\mathrm{X} 2$

$\mathrm{X} 3$

$\mathrm{X} 4$

$\mathrm{X} 5$

$\mathrm{X} 6$

$\alpha 0 \ldots 8$

$\mathrm{U}$

$=$ User Satisfication (TUWEB)

$=$ Attractiveness (TUWEB)

$=$ Dependability (TUWEB)

$=$ Efficiency $($ TUWEB)

$=$ Novelty $($ TUWEB)

$=$ Perspicuity (TUWEB)

$=$ Stimulation (TUWEB)

$=$ Regression coefficien (TUWEB)

$=$ Error term (TUWEB)

$\mathrm{Y}=\alpha 0+\alpha 1 \mathrm{X} 1+\alpha 2 \mathrm{X} 2+\alpha 3 \mathrm{X} 3+\alpha 4 \mathrm{X} 4+\alpha 5 \mathrm{X} 5+\alpha 6 \mathrm{X} 6+\mathrm{u} . \ldots$

$\mathrm{Y}=$ User Satisfication (TUTON)

$\mathrm{X} 1=$ Attractiveness $(\mathrm{TUTON})$

$\mathrm{X} 2=$ Dependability (TUTON)

$\mathrm{X} 3 \quad=$ Efficiency $(\mathrm{TUTON})$

$\mathrm{X} 4 \quad=$ Novelty $(\mathrm{TUTON})$

X5 $\quad=$ Perspicuity $($ TUTON)

X6 $=$ Stimulation $($ TUTON)

$\alpha 0 \ldots 8=$ Regression coefficien (TUTON)

$\mathrm{U}=$ Error term (TUTON) 


$$
\begin{aligned}
& \mathrm{Y}=\alpha 0+\alpha 1 \mathrm{X} 1+\alpha 2 \mathrm{X} 2+\alpha 3 \mathrm{X} 3+\alpha 4 \mathrm{X} 4+\alpha 5 \mathrm{X} 5+\alpha 6 \mathrm{X} 6+\mathrm{u} . \ldots \\
& \mathrm{Y}=\text { User Satisfication (TMK) } \\
& \mathrm{X} 1=\text { Attractiveness }(\mathrm{TMK}) \\
& \text { X2 = Dependability (TMK) } \\
& \mathrm{X} 3=\text { Efficiency }(\mathrm{TMK}) \\
& \text { X4 = Novelty }(\text { TMK) } \\
& \text { X5 = Perspicuity }(\mathrm{TMK}) \\
& \text { X6 = Stimulation }(\mathrm{TMK}) \\
& \alpha 0 \ldots 8=\text { Regression coefficien (TMK) } \\
& \mathrm{U} \quad=\text { Error term }(\mathrm{TMK})
\end{aligned}
$$

To determine the simultaneous effect of independent variables on the dependent variable, the F test was carried out and partially with the T test at the confidence level (95\%).

\section{Results and Discussion}

Open universities provide a wide selection of study assistance services to support student learning activities. This option is intended to meet the needs of PTJJ (Distance Higher Education) study assistance. This is important because we know that UT has a diversity of students of various ages and occupations which of course have different activities. The learning assistance services provided are TUWEB, TUTON and TMK. Therefore, this study will provide an overview of how the user experience (User Experience) and user satisfaction (User Satisfication) of UPBJJ UT Bengkulu are on the three learning aid services.

User Experience and User Satisfication Analysis of Web-Based Tutorial Learning Assistance Services

Table. 3. User Experience Data Web-Based Tutorial Learning Assistance Service

\begin{tabular}{clccc}
\hline No. & Category & Range & Total Respondents & Percentage (\%) \\
\hline $\mathbf{1}$ & Less enough & $24-72$ & 3 & 1,67 \\
$\mathbf{2}$ & Enough & $73-120$ & 30 & 16,66 \\
$\mathbf{3}$ & Good & $121-168$ & 147 & 81,67 \\
& & & $\mathbf{1 8 0}$ & $\mathbf{1 0 0}$ \\
\hline
\end{tabular}

The data above means that the number of students who have user experience in the less category is 3 people or only $1.67 \%$. The good category dominates, namely $81.67 \%$, indicating that users respond positively to the TUWEB study aid service. Based on the information in the questionnaire, these three respondents conveyed signal constraints. Analysis of TUWEB User Experience and User Satisfication was carried out to find out how the experience and satisfaction of students after participating in TUWEB's learning assistance services. TUWEB is a learning service with the help of a virtual tutor. Conducted for 2 hours according to the schedule every week for a period of two months using the MS Teams application. Students can discuss and ask tutors about courses virtually. Based on primary data processing, the following information is obtained; become the biggest obstacle so that they cannot receive the material optimally. The user experience value consists of 6 indicators, namely; attractiveness, dependability, efficiency, novelty, perspicuity, stimulation. Judging from 180 respondents, the dependability indicator obtained the lowest average score (23) and perspicuity (23.8) obtained the highest average score. Dependability describes the clarity of TUWEB ; not as expected / as expected, slow / fast, subjective / objective, or unclear / clear. Perspicuity describes the accuracy of TUWEB ; difficult / easy, confusing / very clear, disorganized / organized, (material) is not appropriate / (material) is appropriate. 
Tabel. 4. Data User Satisfication Web-Based Tutorial Learning Assistance Service

\begin{tabular}{clccc}
\hline No. & Category & Range & Total Respondents & Percentage (\%) \\
\hline $\mathbf{1}$ & Low & $12-28$ & 3 & 1,67 \\
$\mathbf{2}$ & Currently & $29-44$ & 21 & 11,66 \\
$\mathbf{3}$ & High & $45-60$ & 156 & 86,67 \\
& & & $\mathbf{1 8 0}$ & $\mathbf{1 0 0}$ \\
\hline
\end{tabular}

Based on the data above, it is known that the number of students with user satisfaction in the low category is 3 people or only $1.67 \%$. The high category dominates, namely $86.65 \%$ of students are satisfied after participating in TUWEB. Assessment of satisfaction or User Satisfication comes from several indicators as follows; content, accuracy, format, ease of use and timeliness. Ease of use got the highest score (8.8). Students consider TUWEB to be one of the best learning assistance services during a pandemic (easy and practical), because students can easily discuss directly with tutors through video conferencing. This service is appropriate for subjects that are difficult to study independently and require more intense guidance. $73 \%$ of 180 respondents said that network problems were a major problem, especially during bad weather, rain and students in remote areas. Information was also obtained regarding the need for a large quota for TUWEB study assistance services.

\section{Analysis of User Experience and User Satisfication on Online Tutorial Learning Assistance Services}

Analysis of TUTON's User Experience and User Satisfication was carried out to find out how the experience and satisfaction of students after participating in TUTON's learning assistance services. TUTON is a learning service with web elearning. Students are given a topic of discussion every week and assignments in weeks 3, 5, and 7. Based on primary data processing, the following information is obtained;

Table. 5. User Experience Data Online Tutorial Learning Assistance Service

\begin{tabular}{clccc}
\hline No. & Category & Range & Total Respondents & Percentage (\%) \\
\hline $\mathbf{1}$ & Less enough & $24-72$ & 14 & 7,78 \\
$\mathbf{2}$ & Enough & $73-120$ & 26 & 14,44 \\
$\mathbf{3}$ & Good & $121-168$ & 140 & 77,78 \\
& & $\mathbf{1 8 0}$ & $\mathbf{1 0 0}$ \\
\hline
\end{tabular}

The data above means that the number of students who have user experience in the less category is 14 people (7.78\%). A total of 140 users responded positively to the TUTON study aid service. User experience assessment consists of 6 indicators, namely; attractiveness, dependability, efficiency, novelty, perspicuity, stimulation. Judging from 180 respondents, the stimulation indicator obtained the lowest average value (22.7) and attractiveness (23.1) obtained the highest average score. Stimulation describes how to stimulate TUTON ; unhelpful/helpful, unmotivating/motivating, hindering/supportive, passive/encouraging. Attractiveness describes the attractiveness of TUTON ; difficult / easy, confusing / very clear, disorganized / organized, (material) is not appropriate / (material) is appropriate. Based on primary data, the stimulation value obtained the lowest average because students find it difficult when they want to have two-way discussions with tutors, tutors are slow to respond and often get no answers at all. In terms of convenience, TUTON is considered the easiest and most flexible because it allows up to two weeks to answer discussions and assignments. According to research by Zaharah et al (2020) teachers must adapt immediately and innovate and take initiatives to facilitate students to teach in online mode. 
Table. 6. Data User Satisfication Learning Assistance Service Online Tutorial

\begin{tabular}{clcccc}
\hline No. & Category & Range & Total Respondents & Percentage (\%) \\
\hline $\mathbf{1}$ & Low & $12-28$ & 9 & 5,00 \\
$\mathbf{2}$ & Currently & $29-44$ & 16 & 8,89 \\
$\mathbf{3}$ & High & $45-60$ & 155 & 86,11 \\
& & Total & & $\mathbf{1 8 0}$ & $\mathbf{1 0 0}$ \\
\hline
\end{tabular}

The data above means that the number of students who have user experience in the less category is 14 people $(7.78 \%)$. A total of 140 users responded positively to the TUTON study aid service. User experience assessment consists of 6 indicators, namely; attractiveness, dependability, efficiency, novelty, perspicuity, stimulation. Judging from 180 respondents, the stimulation indicator obtained the lowest average value (22.7) and attractiveness (23.1) obtained the highest average score. Stimulation describes how to stimulate TUTON ; unhelpful/helpful, unmotivating/motivating, hindering/supportive, passive/encouraging. Attractiveness describes the attractiveness of TUTON ; difficult / easy, confusing / very clear, disorganized / organized, (material) is not appropriate / (material) is appropriate. Based on primary data, the stimulation value obtained the lowest average because students find it difficult when they want to have two-way discussions with tutors, tutors are slow to respond and often get no answers at all. In terms of convenience, TUTON is considered the easiest and most flexible because it allows up to two weeks to answer discussions and assignments. According to research by Zaharah et al (2020) teachers must adapt immediately and innovate and take initiatives to facilitate students to teach in online mode.

\section{User Experience and User Satisfication Analysis on Course Assignment Assistance Services}

Analysis of the TMK user experience and user satisfaction was conducted to find out how the experience and satisfaction of students after participating in the TMK learning assistance service was. TMK is a learning service that is intended for students who do not register for TUWEB or TUTON so that TMK will automatically be netted. TMK is an essay task that is given in 3 stages at regular intervals. Based on primary data processing, the following information is obtained;

Table. 7. User Experience Data Service Learning Assistance Course Assignments

\begin{tabular}{clccc}
\hline No. & Category & Range & Total Respondents & Percentage (\%) \\
\hline $\mathbf{1}$ & Less enough & $24-72$ & 0 & 0,00 \\
$\mathbf{2}$ & Enough & $73-120$ & 21 & 11,67 \\
$\mathbf{3}$ & Good & $121-168$ & 159 & 88,33 \\
& & & $\mathbf{1 8 0}$ & $\mathbf{1 0 0}$ \\
\hline
\end{tabular}

The data above means that there are no respondents who rate user experience in the poor category. The good category dominates, namely $88.33 \%$ indicating that users respond positively to the TMK learning assistance service. The user experience value consists of 6 indicators, namely; attractiveness, dependability, efficiency, novelty, perspicuity, stimulation. Judging from 180 respondents, the dependability indicator got the lowest average score (24.1) and novelty (24.4) got the highest average score. Dependability describes the clarity of TMK; not as expected / as expected, slow / fast, subjective / objective, or unclear / clear. novelty describes the novelty of TMK; conventional / innovative, not creative / creative, boring / interesting, old / renewable. Respondents felt that they had positive experiences related to their experiences in using TMK learning assistance services. Respondents consider that by following this course assignment, they become more motivated to be creative and are 
required to apply the latest examples / case studies in answering questions. In addition, according to Rahman (2020) stated that some students prefer to learn to use the video conferencing Management System website.

Table. 8. Data User Satisfication Service Study Assistance Course Assignments

\begin{tabular}{clccc}
\hline No. & Category & Range & Total Respondents & Percentage (\%) \\
\hline $\mathbf{1}$ & Low & $12-28$ & 0 & 0,00 \\
$\mathbf{2}$ & Currently & $29-44$ & 15 & 8,33 \\
$\mathbf{3}$ & High & $45-60$ & 165 & 91,67 \\
& & & $\mathbf{1 8 0}$ & $\mathbf{1 0 0}$ \\
\hline
\end{tabular}

Of the three learning assistance services, all three have positive user experience and user satisfaction. More than $75 \%$ of respondents rated the user experience and user satisfaction of TUWEB, TUTON and TMK as being in the good and high categories Based on the data above, it is known that there are no respondents with user satisfaction in the low category, 180 students rated it moderate or high. Assessment of satisfaction or user satisfication comes from the following indicators; content, accuracy, format, ease of use and timeliness. Content got the highest score $(8,9)$. As many as $91.67 \%$ of 180 respondents said they felt high user satisfaction. TMK is a study aid service that is needed, very practical and motivates students to have creativity in answering essay questions. TMK users are students who do not have much time to participate in other assistance services such as TUWEB or TUTON which are considered to require more time. Students give a positive value to TMK and have hope that the TMK learning assistance service will continue. As many as $43 \% \mathrm{OF}$ 180 students expect repair/preparation of the TMK application server which is often down during the assignment upload schedule.

TUWEB, TUTON and TMK study assistance services are available to meet the needs of various students. Students who like to study more intensely, can interact in two directions virtually via video conference will choose TUWEB. Students who find it difficult to find a scheduled time and prefer to study with a more flexible but still focused time will choose TUTON. As for students who don't want to take TUWEB or TUTON, there is a more practical TMK.

\section{Factors Affecting User Satisfaction on TUWEB Learning Assistance Services}

User satisfaction on TUWEB is measured from user ratings of attractiveness, dependability, efficiency, novelty, perspicuity, stimulation. Meanwhile, user satisfaction on TUWEB is measured based on user satisfaction with content, accuracy, format, ease of use and timeliness. To determine the effect of attractiveness, dependability, efficiency, novelty, perspicuity, stimulation variables on the magnitude of TUWEB's user satisfaction, the data is processed using multiple linear regression as follows;

Table 9. Regression Data on Factors that Affect User Satisfaction on Web-Based Tutorial Learning Assistance Services

\begin{tabular}{|c|c|c|c|c|c|c|}
\hline & \multicolumn{3}{|c|}{ R Square } & $\mathbf{F}$ & \multicolumn{2}{|l|}{ Sig. } \\
\hline & \multicolumn{3}{|c|}{.772} & 97.525 & \multicolumn{2}{|c|}{$.000^{\mathrm{a}}$} \\
\hline & \multirow[b]{2}{*}{ Model } & \multicolumn{2}{|c|}{ Unstandardized Coefficients } & $\begin{array}{c}\text { Standardized } \\
\text { Coefficients }\end{array}$ & \multirow{2}{*}{ t } & \multirow[b]{2}{*}{ Sig. } \\
\hline & & B & Std. Error & Beta & & \\
\hline 1 & (Constant) & 13.732 & 1.631 & & 8.417 & .000 \\
\hline & X1 (attractiveness) & -.043 & .151 & -.026 & -.282 & .778 \\
\hline
\end{tabular}




\begin{tabular}{lrrrrr} 
X2 (dependability) & $\mathbf{. 4 2 1}$ & $\mathbf{. 1 7 2}$ & $\mathbf{. 2 4 2}$ & $\mathbf{2 . 4 4 4}$ & $\mathbf{. 0 1 6}$ \\
X3 (efficiency) & -.006 & .189 & -.004 & -.032 & .974 \\
X4 (novelty) & -.084 & .175 & -.048 & -.477 & .634 \\
X5 (perspicuity) & .156 & .173 & .086 & .903 & .368 \\
X6 (stimulation) & $\mathbf{1 . 1 5 4}$ & $\mathbf{. 1 5 6}$ & $\mathbf{. 6 5 9}$ & $\mathbf{7 . 3 7 9}$ & $\mathbf{. 0 0 0}$ \\
\hline
\end{tabular}

\section{F tabel: 2.150}

T tabel: $\mathbf{1 . 6 5 3}$

Based on the table above, it can be seen that the value of $\mathrm{R} 2$ or $\mathrm{R}$ square is 0.772 or equal to (77.2\%). This illustrates that the percentage of the contribution of the independent variable to the dependent variable is $77.2 \%$ or it can be said that the variation of the independent variable used in this model can explain $77.2 \%$ of the variation of the dependent variable. While the remaining $22.8 \%$ is explained or influenced by several variables that are not present and are not included in this model.

The test used to determine the overall effect of the independent variable on the dependent variable is the $F$ test. With a significance level obtained of 0.000 and a calculated $\mathrm{F}$ value > F table (97.525> 2.150) and it can be concluded that these factors have a simultaneous effect on user satisfaction. TUWEB study aid service. Based on the results in the table above, it can be seen that there are 2 variables that have a significant effect on user satisfaction of TUWEB learning aid services. The variables are X2 (dependability) and X6 (stimulation). In the X2 variable (Dependability) obtained T-count $>$ T-tabe $(2.444>1.653)$ and the significance value $(0.016<0.05)$, it can be concluded that the X2 (Dependability) variable affects the user satisfication of TUWEB learning aid services. Variable X6 (stimulation) has a T-count $>$ T-tabe $(7.379>1.653)$ and a significance value $(0.000<0.05)$, it can be concluded that the variable X6 (stimulation) has an effect on user satisfication of TUWEB learning aid services. Meanwhile, several other variables such as X1 (attractiveness), X3 (efficiency), X4 (novelty), X5 (perspicuity) did not significantly affect user satisfication of TUWEB learning aid services. So in an effort to increase user satisfaction with TUWEB learning assistance services, managers can increase dependability and stimulation.

\section{Factors Affecting User Satisfaction on TUTON Learning Assistance Services}

User satisfaction on TUTON is measured by user ratings of attractiveness, dependability, efficiency, novelty, perspicuity, stimulation. Meanwhile, user satisfaction for TUTON is measured based on user satisfaction with content, accuracy, format, ease of use and timeliness. To determine the effect of attractiveness, dependability, efficiency, novelty, perspicuity, stimulation variables on the magnitude of TUTON's user satisfaction, the data is processed using multiple linear regression as follows;

Table. 10. Regression Data on Factors That Affect User Satisfication on Online Tutorial Learning Assistance Services

\begin{tabular}{|c|c|c|c|c|c|c|}
\hline \multicolumn{3}{|c|}{ R Square } & \multicolumn{2}{|r|}{$\mathbf{F}$} & \multicolumn{2}{|c|}{ Sig. } \\
\hline & \multicolumn{2}{|l|}{.847} & \multicolumn{2}{|c|}{159.147} & \multicolumn{2}{|c|}{$.000^{\mathrm{a}}$} \\
\hline & & Unstandardized & oefficients & $\begin{array}{c}\text { Standardized } \\
\text { Coefficients }\end{array}$ & & Sig. \\
\hline \multicolumn{2}{|c|}{ Model } & B & Std. Error & Beta & $\mathrm{t}$ & \\
\hline \multirow[t]{2}{*}{1} & (Constant) & 14.420 & 1.287 & & 11.200 & .000 \\
\hline & X1 (attractiveness) & .618 & .250 & .343 & 2.471 & .014 \\
\hline
\end{tabular}




\begin{tabular}{|c|c|c|c|c|c|}
\hline \multicolumn{3}{|c|}{$\begin{array}{l}\text { Jurnal Kependidikan: } \\
\text { Jurnal Hasil Penelitian dan Kajian Kepustakaan } \\
\text { di Bidang Pendidikan, Pengajaran dan Pembelajaran } \\
\text { https://le-journal.undikma.ac.id/index.php/jurnalkependidikan/index }\end{array}$} & \multicolumn{3}{|c|}{$\begin{array}{r}\text { Vol. 7, No. } 4 \text { : December } 2021 \\
\text { E-ISSN: } 2442-7667 \\
\text { pp. } 981-993 \\
\text { Email: jklppm@undikma.ac.id }\end{array}$} \\
\hline $\mathrm{X} 2$ (dependability) & -.366 & .275 & -.207 & -1.331 & .185 \\
\hline X3 (efficiency) & .408 & .213 & .250 & 1.914 & .057 \\
\hline X4 (novelty) & -.047 & .225 & -.030 & -.209 & .835 \\
\hline X5 (perspicuity) & .491 & .249 & .290 & 1.986 & .049 \\
\hline X6 (stimulation) & .466 & .235 & .294 & 1.990 & .048 \\
\hline
\end{tabular}

F table: 2.150

T table: 1.653

Based on the table above, it can be seen that the value of R2 or R square is 0.847 or equal to $(84.7 \%)$. This illustrates that the percentage of the contribution of the independent variable to the dependent variable is $84.7 \%$ or it can be said that the variation of the independent variable used in this model can explain $84.7 \%$ of the variation of the dependent variable. While the remaining $15.3 \%$ is explained or influenced by several variables that are not present and are not included in this model.

The test used to determine the overall effect of the independent variable on the dependent variable is the $\mathrm{F}$ test. With a significance level obtained of 0.000 and a calculated $\mathrm{F}$ value $>\mathrm{F}$ table $(159.147>2.150)$ and it can be concluded that these factors simultaneously affect user satisfaction. TUTON's study aid service. Based on the results in the table above, it can be seen that there are 3 variables that have a significant effect on user satisfaction of the TUTON learning aid service. The variables are X1 (attractiveness), X5 (perspicuity), X6 (stimulation). In the variable X1 (attractiveness) obtained T-count> T-tabe (2.471> 1.653) and the significance value $(0.014<0.05)$, it can be concluded that the variable X1 (attractiveness) has an effect on user satisfication of the TUTON learning aid service. Variable X5 (perspicuity) obtained T-count>T-tabe (1.986>1.653) and a significance value $(0.049<0.05)$, it can be concluded that the variable X5 (perspicuity) has an effect on user satisfication of the TUTON learning aid service. Variable X6 (stimulation) obtained Tcount $>$ T-tabe $(1.990>1.653)$ and a significance value $(0.048<0.05)$, it can be concluded that the variable X6 (stimulation) has an effect on user satisfication of the TUTON learning aid service. Meanwhile, several other variables, such as X2 (dependability), X3 (efficiency), X4 (novelty), did not significantly affect the user satisfaction of the TUTON learning aid service. So in an effort to increase user satisfaction with TUTON learning assistance services, managers can increase attractiveness, perspicuity, stimulation.

\section{Factors Affecting User Satisfication on TMK Learning Assistance Services}

User satisfaction of TMK is measured by user ratings of attractiveness, dependability, efficiency, novelty, perspicuity, stimulation. Meanwhile, user satisfaction with TMK is measured based on user satisfaction with content, accuracy, format, ease of use and timeliness. To determine the effect of attractiveness, dependability, efficiency, novelty, perspicuity, stimulation variables on the magnitude of the TMK user satisfaction, the data is processed using multiple linear regression as follows;

Based on table 4.4.3.1. it can be seen that the value of $\mathrm{R} 2$ or $\mathrm{R}$ square is 0.750 or equal to $(75.0 \%)$. This illustrates that the percentage contribution of the independent variable to the dependent variable is $75.0 \%$. or it can be said that the variation of the independent variable used in this model can explain $75.0 \%$ of the variation of the dependent variable. While the remaining $25.0 \%$ is explained or influenced by several variables that are not present and are not included in this model. 
Table. 11. Regression Data on Factors that Affect User Satisfication on Coursework Learning Assistance Services

\begin{tabular}{|c|c|c|c|c|c|c|}
\hline \multicolumn{4}{|c|}{ R Square } & $\mathbf{F}$ & \multicolumn{2}{|c|}{ Sig. } \\
\hline \multicolumn{4}{|c|}{.750} & 159.147 & \multicolumn{2}{|c|}{$.000^{\mathrm{a}}$} \\
\hline \multirow{2}{*}{\multicolumn{2}{|c|}{ Model }} & \multicolumn{2}{|c|}{$\begin{array}{l}\text { Unstandardized } \\
\text { Coefficients }\end{array}$} & \multirow{2}{*}{$\begin{array}{l}\text { Standardized } \\
\text { Coefficients } \\
\text { Beta }\end{array}$} & \multirow[t]{2}{*}{$\mathbf{t}$} & \multirow[t]{2}{*}{ Sig. } \\
\hline & & B & Std. Error & & & \\
\hline \multirow{7}{*}{1} & (Constant) & 15.654 & 1.832 & & 8.547 & .000 \\
\hline & X1 (attractiveness) & .180 & .190 & .105 & .947 & .345 \\
\hline & $\mathrm{X} 2$ (dependability) & .135 & .189 & .078 & .714 & .476 \\
\hline & X3 (efficiency) & -.213 & .236 & -.111 & -.904 & .368 \\
\hline & X4 (novelty) & .724 & .236 & .402 & 3.067 & .003 \\
\hline & X5 (perspicuity) & .959 & .210 & .584 & 4.572 & .000 \\
\hline & X6 (stimulation) & -.274 & .257 & -.163 & -1.068 & .287 \\
\hline
\end{tabular}

F tabel: 2.150

T tabel: 1.653

The table above shows the test used to determine the overall effect of the independent variable on the dependent variable is the $\mathrm{F}$ test. With a significance level obtained of 0.000 and an $\mathrm{F}$ arithmetic value> $\mathrm{F}$ table (159.147> 2.150) and it can be concluded that these factors have a simultaneous effect. on user satisfication of TMK learning aid services.

Based on the outputs produced in the table above, it can be seen that there are 2 variables that have a significant effect on user satisfaction of TMK learning aid services. The variables are X3 (efficiency), X4 (novelty). In the X3 variable (efficiency) obtained Tcount $>$ T-tabe $(3.067>1.653)$ and the significance value $(0.003<0.05)$, it can be concluded that the X3 variable (efficiency) has an effect on user satisfication of TMK learning aid services. Variable X4 (novelty) has a T-count $>\mathrm{T}$-tabe $(4.572>1.653)$ and a significance value $(0.000<0.05)$, it can be concluded that the variable X4 (novelty) has an effect on user satisfication of TMK learning aid services. Meanwhile, several other variables, such as X1 (attractiveness), X2 (dependability) X5 (perspicuity, X6 (stimulation), did not significantly affect user satisfaction of TMK learning aid services. So in an effort to increase user satisfaction with TMK learning aid services, managers can improve efficiency novelty.

Based on user experience and user satisfaction analysis, TUWEB, TUTON AND TMK learning assistance services are known to have their respective advantages and disadvantages. The TUWEB, TUTON AND TMK study assistance services have their own users tailored to the needs of each student. Although its role can not replace face-to-face tutorials but the service is helpful. The same thing was stated by Abubakar \& Tsuraya (2021) that there is no perfect digital platform that can replace face-to-face learning because many things are lost during this online learning. So, in order to keep running effectively, a combination of several platforms is needed to be utilized.

\section{Conclusion}

The conclusions obtained from the results of this study were as many as 81.67 users of TUWEB learning aid services had a good experience and $86.65 \%$ of students felt high satisfaction with TUWEB's learning aid services. The obstacles faced by students in this study aid service are signal disturbances, weather and the amount of quota used during TUWEB. A total of 77.78 users of TUTON's learning aid services felt a good experience and 
$86.11 \%$ of students felt high satisfaction with Tuton's learning aid services. The obstacle faced by students in this study aid service is the lack of tutor response to the problems faced by the students of the TUTON study aid service. A total of $91.67 \%$ of users of TMK learning aid services felt a good experience and $88.33 \%$ of students felt high satisfaction with TMK learning aid services. The obstacle faced by students in this study assistance service is website error / server down during assignment upload hours.

Variables that have a significant effect on user satisfaction of TUWEB learning aid services are dependability and stimulation. Variables that have a significant effect on user satisfaction of TUTON learning aid services are attractiveness, perspicuity and stimulation. Variables that have a significant effect on user satisfaction of TMK learning aid services are efficiency and novelty.

\section{Recommendation}

Recommendation that can be submitted are for UT leaders; (1) To minimize obstacles in the TUWEB study assistance service, it is necessary to provide access to TUWEB recordings so that students who cannot participate due to signal problems can play back the video conference. And to overcome the use of a large quota, managers can consider using a conference application that is more quota-efficient. To minimize obstacles in the TUTON study assistance service, it is necessary to encourage or provide a time limit so that tutors are more responsive. To minimize obstacles in TMK learning assistance services, IT and managers need to seek things that can minimize the occurrence of servers not being down, such as improving website performance and making regular upload schedules. (2) Variables that have a significant effect on user satisfaction of TUWEB learning aid services are dependability and stimulation, so in an effort to increase user satisfaction with TUWEB learning aid services, managers can increase dependability and stimulation. Variables that have a significant effect on user satisfaction of TUTON learning aid services are attractiveness, perspicuity and stimulation, so in an effort to increase user satisfaction with TUTON learning assistance services, managers can increase attractiveness, perspicuity and stimulation. Variables that have a significant effect on user satisfaction of TMK learning aid services are efficiency and novelty, so in an effort to increase user satisfaction with TMK learning aid services, managers can improve efficiency and novelty.

\section{References}

Abidin, Z., Rumansyah., \& Arizona, K. (2020). Pembelajaran Online Berbasis Proyek Salah Satu Solusi Kegiatan Belajar Mengajar di Tengah Pandemi Covid-19. Jurnal Ilmiah Profesi Guru, 5(1), 64-70.

Abubakar, M., \& Tsuraya, A. S. (2021). Investigating Students' Eyesights in the Utilization of Platforms in Learning ESP During the Covid-19 Pandemic. Seltics, 4(1), 1-16. https://doi.org/10.46918/seltics.v4i1.954

Aji, R. H. S. (2020). Dampak Covid19 pada Pendidikan di Indonesia :https://doi.org/10.15408/sjsbs.v7i5.15314

Arikunto, Suharsimi 2012. Prosedur Penelitian Suatu Pendekatan Praktis. Edisi Revisi VI. Jakarta: PT. Rineka Cipta.Bailey, J. E., \& Sammy W., P. 1983. Development of a Tool for Measuring and Analysing Computer User Satisfaction. Management Science , 29 (5), 530 - 545.

Artayasa, I., Fitriani, T., Handayani, B., \& Kusmiyati, K. (2021). Efektivitas Penerapan Model Pembelajaran Think Talk Write (TTW) Secara Online Terhadap Literasi Informasi Siswa SMA. Jurnal Kependidikan: Jurnal Hasil Penelitian dan Kajian 
Kepustakaan di Bidang Pendidikan, Pengajaran dan Pembelajaran, 7(3), 641-648.

Cerejo, L. (2012). The Elements Of The Mobile Experience. Https://www.Smashingmagazine.Com/2012/07/Elements-Mobile-UserExperience.

Didik, P. (2020). Pembelajaran Bahasa Indonesia Vol 9 No 2 , Oktober 2020 Jurnal Pendidikan dan Pembelajaran Bahasa Indonesia Vol 9 No 2 , Oktober 2020. 9(2).

Harjanto, T., \& Sumunar, D. S. E. W. (2018). Tantangan Dan Peluang Pembelajaran Dalam Jaringan: Studi Kasus Implementasi Elok (E-Learning: Open For Knowledge Sharing) Pada Mahasiswa Profesi Ners. Jurnal Keperawatan Respati Yogyakarta, 5, 24-28.

I. G. N. S. Wijaya, E. Triandini, E. T. G. Kabnani, and S. Arifin (2021) "E-commerce website service qualityand customer loyalty using WebQual 4.0 with importance performances analysis, and structural equation model: An empirical study in shopee," Regist. J. Ilm. Teknol. Sist. Inf., vol. 7, no. 2, pp. 107-124, 2021, doi: 10.26594/register.v7i2.2266.

Nazir, Moh. (2014). Metode Penelitian. Bogor: Ghalia Indonesia.

Nurgiantoro, Burhanudin.(2009). Penilaian Pengajaran Bahasa dan Sastra, edisi ketiga. Yogyakarta: BPFE.

Pusdiklat Kemdikbud. (2020). Surat Edaran Mendikbud No 4 Tahun 2020 Tentang Pelaksanaan Kebijakan Pendidikan Dalam Masa Darurat Penyebaran Corona Virus Disease (COVID-19) Pusdiklat Pegawai Kementerian Pendidikan dan Kebudayaan. Https://Pusdiklat.Kemdikbud.Go.Id/.

Rahman, K. (2020). Learning Amid Crisis: Efl Students' Perception On Online Learning During Covid-19 Outbreak. Eternal (English, Teaching, Learning, and Research Journal). https://doi.org/10.24252/eternal.v62.202 0.a1

Rosali, E. S., Pendidikan, J., \& Universitas, G. (2020). Aktifitas pembelajaran daring pada masa pandemi covid -19. 1, 21-30.

Shim, J.K., dan Siegel, J.G. (2001). Budgeting. Jakarta: Penerbit Erlangga.

Sil, Muhanmad. (2018). Perilaku Tutor Dalam Pengelolaan Tutorial Terhadap Kinerjanya Pada Universitas Terbuka Bengkulu. Kajian Teori Pengembangan Sumber Daya Manusia: Universitas Terbuka.

Siregar, M., Rokhmawati2, Retno I, Az-Zahra, Hanifah M. (2019). Evaluasi Usability dan Pengalaman Pengguna Website Zenius.net Menggunakan Metode TUXEL: A Technique for User Experience Evaluation in e-Learning. Jurnal Pengembangan Teknologi Informasi dan Ilmu Komputer e-ISSN: 2548-964X Vol. 3, No. 5, Mei 2019, hlm. 5058-5067.

Sugiyono. (2014). Metode Penelitian Pendidikan Pendekatan Kuantitatif, Kualitatif Dan $R \& D$. Bandung : Alfabeta.

Universitas terbuka. (2015).Sistem Pembelajaran. Diakses pada https ://www.ut.ac.id. Pada 7 Februari 2020

Universitas terbuka. (2020).Sistem Pembelajaran. Diakses pada https ://www.ut.ac.id. Pada 7 Februari 2020

Wisudiawan, Gede A.A. (2013). Kepuasan Pengguna. Jurnal Ilmiah Teknologi Informasi Terapan Volume II. (No 1), hal 55-59.

Zaharah, Z., Kirilova, G. I., \& Windarti, A. (2020). Impact of Corona Virus Outbreak Towards Teaching and Learning Activities in Indonesia: Jurnal Sosial Dan Budaya Syar-I. 